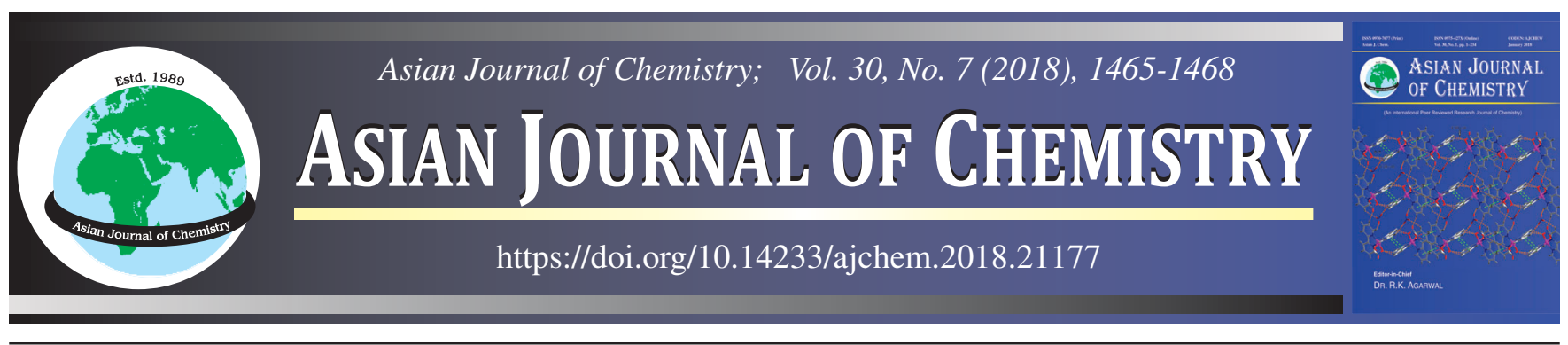

\title{
Synthesis, Characterization and Antibacterial Studies of Silver Complex of 3-Aminopropyltriethoxysilane
}

Hayder Hamied Mihsen ${ }^{1, *}$, Nesser Kadham Shareef ${ }^{1}$ and Wafaa Sadeq Alwazni ${ }^{2}$

${ }^{1}$ Department of Chemistry, College of Science, University of Kerbala, Kerbala, Iraq

${ }^{2}$ Department of Biology, College of Science, University of Kerbala, Kerbala, Iraq

*Corresponding author: E-mail: hayderalhmedawy@gmail.com

Received: 11 December 2017;

Accepted: 22 January 2018;

Published online: 31 May 2018;

AJC-18915

A new complex of silver, $\left[\mathrm{Ag}(\mathrm{APTES})_{2} \mathrm{NO}_{3}\right]$ using 3-aminopropyltriethoxysilane (APTES) as a ligand has been symthesized. The new
complex was characterized by molar conductance measurement, UV-visible, infrared, nuclear magnetic resonance, thermogravimetry and
atomic absorption spectroscopy. FT-IR and ${ }^{1} \mathrm{H}$ NMR analyses indicated that ligand APTES and $\mathrm{NO}_{3}{ }^{-}$ion are coordinated to the silver ion via
nitrogen amino group and oxygen nitro group, respectively. Molar conductance value for the complex indicates that the complex is non-
electrolyte. While TGA-DTA analysis showed that the degradation of complex occurs between $200-593{ }^{\circ} \mathrm{C}$. The complex assume triagonal
geometry in which $\mathrm{Ag}(\mathrm{I})$ have two molecules of APTES and one molecule from ionic nitrate in the coordination sphere. The new complex
of [Ag(APTES) $\left.\mathrm{NO}_{3}\right]$ showed pronounced antibacterial effect against proteus $(P$. mirablis) bacteria isolated from patient with urinary
tract infection. Also had been exhibited a clear decrease in the ability of tested bacteria to form biofilm after treating with MIC of complex.
Keywords: 3-Aminopropyltriethoxysilane, Silver nitrate, Antibiofilm efficacy.

\section{INTRODUCTION}

3-Aminopropyltriethoxysilane (APTES) is commonly used in the preparation of a highly porous fiber coating material due to its amine group [1]. Amino-terminated silica particles can be used as filler in rubber and plastic to increase the tensile strength, improve the rheological behaviour [2]. The reaction of APTES with transition metal ions must performed in nonaqueous phase such as dry ethanol or dry benzene or hexane to avoid the hydrolysis of APTES to ethanol and trisilanol [3-6].

3-Aminopropyltriethoxysilane (APTES) can be used in the general reaction for synthesis of functionalized ligands. The functionalized ligands were obtained by the reaction of salicylaldehyde with 3-aminopropyltriethyoxysilane. The ligand was characterized by FT-IR and ${ }^{1} \mathrm{H}$ NMR analyses. The salicylaldimine ligands were reacted with either $\mathrm{Cu}$ (II) or Pd(II) salts to form both model and functionalized $\mathrm{Cu}$ (II) and $\mathrm{Pd}$ (II) complexes [3]. 3-Aminopropyltriethoxysilane (APTES) used in electron exchange columns and used in the application ranging from removal of contaminants wastewater [7-12]. A huge number of studies showed spread the existence of an antibiotic-resistant bacteria in the general population and can be particularly dangerous when infected human. Bacterial and biofilm associated infection are probably the leading causes of severe nosocomial problems [13].
Silver consists of antibacterial properties and prevent infection such as it used empirically to treat ulcers and burns as well as used in treating warts and eyes infection [14,15]. Numerous articles reported the antibacterial activity of silver metal ion till date. However, a limited studies investigating the antibiofilm activity of silver metal of $P$. mirablis bacteria, therefore, the present project was designated to determine this activity for new complex of $\left[\mathrm{Ag}(\mathrm{APTES})_{2} \mathrm{NO}_{3}\right]$.

\section{EXPERIMENTAL}

All the chemicals used of reagent grade (Sigma-Aldrich, $\mathrm{BDH}$ ) and used as such, however, the solvents used were purified. The molar conductance measurements of the complex were measured in methanol at room temperature using Digital Conductivity Meter-WT-700-inolab. The electronic spectra of solution of the complex and ligand in methanol solution $\left(10^{-3}\right.$ M) concentration were recorded in UV-visible spectrophotometer-1800, Shimadzu. FTIR spectra of ligand and its complex were recorded using $\mathrm{KBr}$ pellets in Shimadzu spectrophotometer. The ${ }^{1} \mathrm{H}$ NMR spectra were recorded in DMSO- $d_{6}$ solution using TMS as the internal standard in $500 \mathrm{MHz}$ NMR spectrophotometer [Bruker, Germany]. Thermal analyses of sample were performed at heating range $\left(25-600^{\circ} \mathrm{C}\right)$ using STAPT1000 Linseis, Germany. While the metal content of complex 
was determined by atomic absorption technique using Japan AA-67G Shimadzu model.

Synthesis of silver complex: About $0.5 \mathrm{~g}(2.95 \mathrm{mmol})$ of silver nitrate dissolved in $10 \mathrm{~mL}$ of absolute methanol was mixed with $1.37 \mathrm{~mL}$ (2.94 mmol) of 3-aminopropyltriethoxysilane (APTES) in $10 \mathrm{~mL}$ absolute methanol with continuous stirring of mixture in bottomed flask at $50{ }^{\circ} \mathrm{C}$. There was an immediate development of pale yellow colour solution and the solution was continuously stirred for about $2 \mathrm{~h}$. The pale yellow compound obtained was filtered off and dried under oven. The product was recrystallized from absolute methanol, (Scheme-I).<smiles></smiles>

Scheme-I: Preparation of new complex $\left[\mathrm{Ag}(\mathrm{APTES})_{2} \mathrm{NO}_{3}\right]$

Isolation of bacteria: The Proteus mirablis was obtained from the Microbiology laboratory of Biology Department, College of Science, Kerbala University, Kerbala, Iraq. The identification of this isolate was carried out according to biochemical tests and API-20 system [16,17].

Antibiotic sensitivity test: Bacterial sensitivity to antibiotic was detected according to the reported method [18].

Detection of biofilm formation activity: The biofilm formation ability of isolated bacteria was determined by tub methods as described by Mathur et al. [19] and by tissue culture plate methods as described by Maldonado et al. [20].

Determination of minimum inhibitory concentration (MIC) of complex [Ag(APTES $)_{2} \mathbf{N O}_{3}$ ]: The agar dilution method [21] was used to detect MIC of the complex [Ag(APTES $\left.)_{2} \mathrm{NO}_{3}\right]$.

\section{RESULTS AND DISCUSSION}

The complex having general formula $\left[\mathrm{Ag}(\mathrm{APTES})_{2} \mathrm{NO}_{3}\right]$ was synthesized by reaction of APTES and $\mathrm{AgNO}_{3}$, which is soluble in hot absolute methanol. The complex decompose above $350^{\circ} \mathrm{C}$. The low molar conductance $\left(20 \mu \mathrm{cm}^{-1}\right)$ of complex in absolute methanol revealed the non-electrolytic nature of the complex. According to atomic absorption measurement, silver content of the complex was $17.6 \%$. Table- 1 shows the physical properties of APTES and its silver complex.

TABLE-1

ANALYTICAL AND MOLAR CONDUCTANCE DATA OF THE LIGAND AND ITS SILVER COMPLEX

\begin{tabular}{lccc}
\hline Compound & Colour & $\begin{array}{c}\mathrm{Ag}(\%) \\
\text { Calcd. } \\
(\text { Prac. })\end{array}$ & $\begin{array}{c}\Lambda_{\mathrm{m}} \times 10^{-3} \\
\left(\mathrm{mho} \mathrm{cm}^{2}\right. \\
\left.\mathrm{mol}^{-1}\right)\end{array}$ \\
\hline APTES & Colorless & - & - \\
{$\left[\mathrm{Ag}(\mathrm{APTES})_{2} \mathrm{ONO}_{2}\right]$} & Pale yellow & $17.3(17.6)$ & 20 \\
\hline APTES $=$ 3-Aminopropyltriethoxysilane & &
\end{tabular}

The key bands of FTIR measurements are shown in Table-2, which indicated that ligand APTES have one essential groups,

\begin{tabular}{lcccc}
\hline \multicolumn{5}{c}{ TABLE-2 } \\
CHARACTERISTIC FTIR BANDS OF THE \\
LIGAND AND ITS SILVER COMPLEX \\
\hline \multirow{3}{*}{ Compound } & \multicolumn{5}{c}{ Frequency $\left(\mathrm{cm}^{-1}\right)$} \\
\cline { 2 - 5 } & $\begin{array}{c}v(\mathrm{~N}-\mathrm{H}) \\
\text { asy. }\end{array}$ & $\begin{array}{c}\text { s }(\mathrm{N}-\mathrm{H}) \\
\text { sym. }\end{array}$ & $v(\mathrm{M}-\mathrm{N})$ & $v(\mathrm{M}-\mathrm{O})$ \\
\hline APTES & 3369.7 & 3298.3 & - & - \\
$\left.[\text { Ag(APTES })_{2} \mathrm{ONO}_{2}\right]$ & 3340.8 & 3269.4 & 549 & 443 \\
\hline
\end{tabular}

Asy. $=$ asymmetric stretching; sym. $=$ symmetric stretching

which is $-\mathrm{NH}_{2}$, when linked to the metal ion via nitrogen a shift to lower or higher frequency would occurs [22]. Another group of bands appeared at 2885,1076 and $783 \mathrm{~cm}^{-1}$ is attributed due to $v\left(-\mathrm{CH}_{2}\right)[23], v(\mathrm{Si}-\mathrm{O})$ [24] and $v\left(\mathrm{O}-\mathrm{CH}_{3}\right)$ [25], respectively. The frequency $v(\mathrm{~N}-\mathrm{H})$ for APTES in the range $3369-3298 \mathrm{~cm}^{-1}$ was shifted to the lower energy range $3340-3269 \mathrm{~cm}^{-1}$ in the complex $\left[\mathrm{Ag}(\mathrm{APTES})_{2} \mathrm{ONO}_{2}\right.$ ]. This confirmed the coordination of amine nitrogen to the silver ion. The stretching frequency of nitro $v(-N O)$ appeared at 1477 and $933 \mathrm{~cm}^{-1}$ [22]. The evidence of nitrogen atom and oxygen of nitrate ion coordinated with metal ion demonstrated by the new bands appearing at 549 and $443 \mathrm{~cm}^{-1}$ are assigned to $v(\mathrm{Ag}-\mathrm{N})$ and $v(\mathrm{Ag}-\mathrm{O})$ modes, respectively $[26,27]$.

The electronic absorption spectrum of the complex was recorded in absolute methanol. By comparing the electronic spectrum of the APTES and its silver complex (Figs. 1-2) the spectrum of complex was shifted move to lower energy (red shifting). And shows the number of peaks belong to $n-\pi^{*}$ transition in nitro group in complex $[28,29]$. The $\left[\mathrm{Ag}(\mathrm{APTES})_{2} \mathrm{ONO}_{2}\right]$ complex is diamagnetic as expected for $d^{10}$ system, therefore, the proposed structure is triagonal geometry for this complex [29].

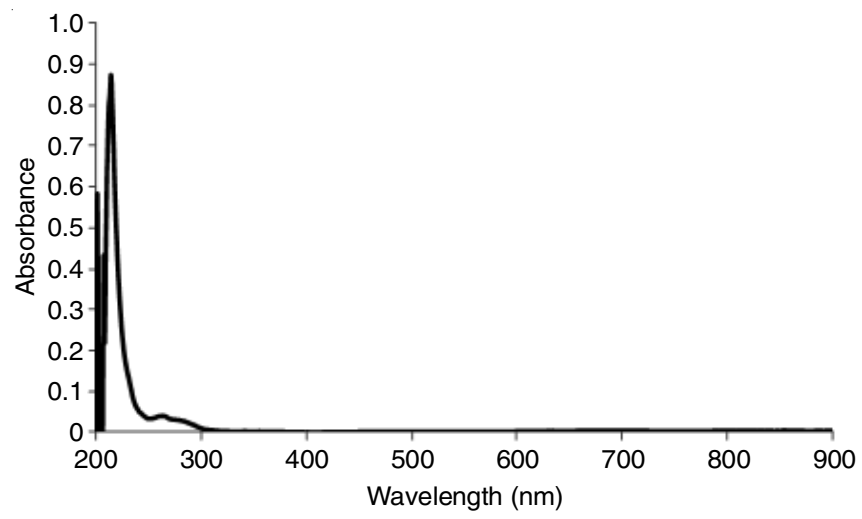

Fig. 1. UV-visible spectrum for APTES

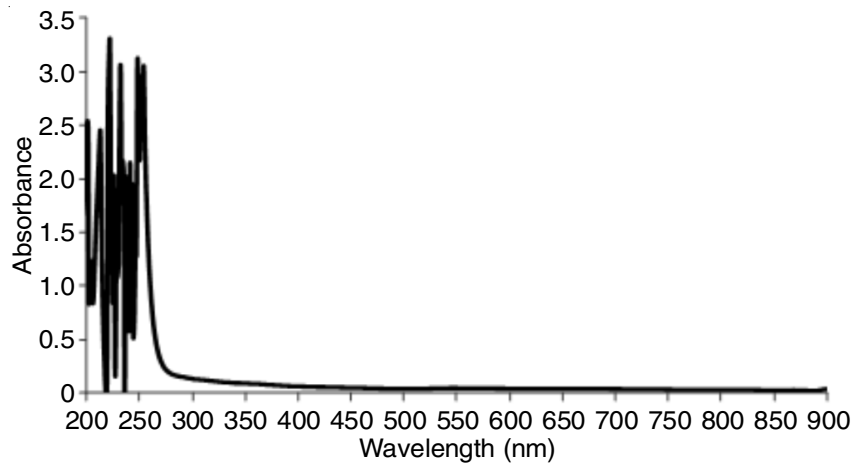

Fig. 2. UV-visible spectrum for $\left[\mathrm{Ag}(\mathrm{APTES})_{2} \mathrm{ONO}_{2}\right]$ 
TABLE-3

THERMAL DECOMPOSITION OF COMPLEX $\left[\mathrm{Ag}(\mathrm{APTES})_{2} \mathrm{NO}_{3}\right]$

\begin{tabular}{|c|c|c|c|c|c|}
\hline \multirow{2}{*}{ Complex } & \multicolumn{2}{|c|}{ Weight loss $(\%)$} & \multirow{2}{*}{$\begin{array}{c}\text { Thermal range } \\
\left({ }^{\circ} \mathrm{C}\right)\end{array}$} & \multirow{2}{*}{ Decomposed product } & \multirow{2}{*}{ Compound product } \\
\hline & Found & Calcd. & & & \\
\hline \multirow{3}{*}{$\mathrm{C}_{18} \mathrm{H}_{46} \mathrm{~N}_{3} \mathrm{O}_{9} \mathrm{AgSi}_{2}$} & 8.6 & 8.7 & $200-334.9$ & $-\mathrm{NO}_{2}$ & $\mathrm{AgO}, 2 \mathrm{CH}_{3} \mathrm{CH}_{2} \mathrm{O}-, 2 \mathrm{SiO}_{2}, 4 \mathrm{CH}_{3} \mathrm{CH}_{2^{-}}, 2\left(\mathrm{CH}_{2}\right)_{3} \mathrm{NH}_{2}$ \\
\hline & 19.0 & 19.9 & $334.9-470$ & $2 \mathrm{NH}_{3}, \mathrm{CO}_{2}, \mathrm{CH}_{3} \mathrm{CH}_{2} \mathrm{CH}_{3}$ & $\mathrm{AgO}, 2 \mathrm{SiO}_{2}, 4 \mathrm{CH}_{3} \mathrm{CH}_{2^{-}}, 2\left(\mathrm{CH}_{2}\right)_{3^{-}}$ \\
\hline & 9.42 & 9.46 & $470-593$ & $2 \mathrm{CH}_{3} \mathrm{CH}_{2-}$ & $\mathrm{AgO}, 2 \mathrm{SiO}_{2} ; 2 \mathrm{CH}_{3}\left(\mathrm{CH}_{2}\right)_{4^{-}}$ \\
\hline
\end{tabular}

According to the literature [30], proton chemical shift assignments for APTES in ${ }^{1} \mathrm{H}$ NMR technique at $\mathrm{pH}=7$ in $\mathrm{D}_{2} \mathrm{O}$ as follow: $\delta 0.71$ ppm belong to $\left(\mathrm{Si}-\mathrm{CH}_{2}-\mathrm{CH}_{2}-\mathrm{CH}_{2}\right.$ ), $1.77 \mathrm{ppm}$ belong to $\left(\mathrm{Si}-\mathrm{CH}_{2}-\mathrm{CH}_{2}-\mathrm{CH}_{2}\right), 2.59 \mathrm{ppm}$ belong to $\left(\mathrm{Si}-\mathrm{CH}_{2}-\mathrm{CH}_{2}-\mathrm{CH}_{2}-\right.$ $\mathrm{NH}_{2}$ ), 3.00 ppm belong to ( $\mathrm{Si}-\mathrm{Si}-\mathrm{CH}_{2}-\mathrm{CH}_{2}-\mathrm{CH}_{2}$ ), 1.72 ppm belong to $-\mathrm{Si}-\mathrm{OCH}_{2}-\mathrm{CH}_{3}, 3.64 \mathrm{ppm}$ belong to $\left(-\mathrm{Si}-\mathrm{OCH}_{2}-\mathrm{CH}_{3}\right)$. For complex $\left[\mathrm{Ag}(\mathrm{APTES})_{2} \mathrm{NO}_{3}\right]$, the signals of amine group and other protons for APTES ligand are shifted and some it were changed in intensity, this good evidence that complex was formed [30,31], 0.322-0.329 ppm belong to $\left(\mathrm{Si}-\mathrm{CH}_{2}-\mathrm{CH}_{2}-\mathrm{CH}_{2}\right), 1.136-$ $1.148 \mathrm{ppm}$ belong to $\left(\mathrm{Si}-\mathrm{CH}_{2}-\mathrm{CH}_{2}-\mathrm{CH}_{2}\right), 2.49 \mathrm{ppm}$ belong to ( $\mathrm{Si}-\mathrm{CH}_{2}-\mathrm{CH}_{2}-\mathrm{CH}_{2}-\mathrm{NH}_{2}$ ), 3.30 ppm belong to $\left(\mathrm{Si}-\mathrm{CH}_{2}-\mathrm{CH}_{2}-\mathrm{CH}_{2}\right.$ ), $1.891 \mathrm{ppm}$ belong to $-\mathrm{Si}-\mathrm{OCH}_{2}-\mathrm{CH}_{3}, 4.11-4.15 \mathrm{ppm}$ belong to $\left(-\mathrm{Si}-\mathrm{OCH}_{2}-\mathrm{CH}_{3}\right)$.

Thermal analysis of complex $\left[\mathrm{Ag}(\mathrm{APTES})_{2} \mathrm{NO}_{3}\right]$ was studied by TGA/DTA techniques through the range $\left(25-600{ }^{\circ} \mathrm{C}\right)$ at a heating rate $10^{\circ} \mathrm{C} / \mathrm{min}$ under nitrogen atmosphere are shown in Table-3 and their thermogram are showed in Fig. 3. Steps of thermal decomposition at maximum temperature of TGA are recorded with weight loss. Table-3 shows the decomposition stages, which replicate the nature of binding between metal and ligand (APTES) and the stability of complex [32].

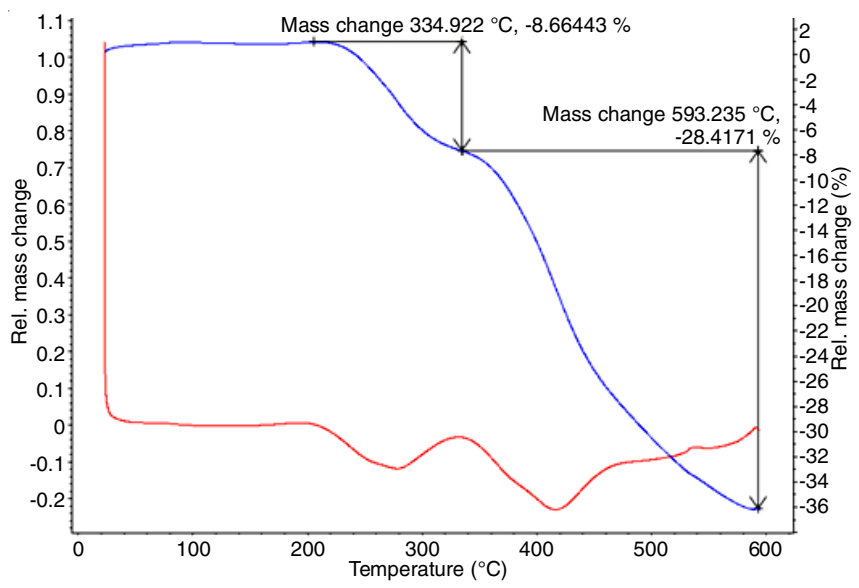

Fig. 3. Thermogram of $\left[\mathrm{Ag}(\mathrm{APTES})_{2} \mathrm{ONO}_{2}\right]$

Antibacterial and antibiofilm activities: The antibiofilm efficacy of new complex was detected against multidrug resist strain of $P$. mirablis bacteria. The results of this study showed that MIC of silver complex was $5 \times 10^{-4} \mathrm{M}$ but for the free silver ion reached to $7.5 \times 10^{-4} \mathrm{M}$. This results is in agreement with previous studies [33] in which silver components exhibited antibacterial activity with $99 \%$ killing effect because the continuous uptakes of silver by the bacteria.

The results also illustrated that $P$. mirablis was high producer for biofilm formation (1.9 O.D.) but the optical density reduced to 0.15 O.D., when the MIC of $\left[\mathrm{Ag}(\mathrm{APTES})_{2} \mathrm{NO}_{3}\right]$ complex was added to bacterial suspension in compare to free silver ion $(0.95$

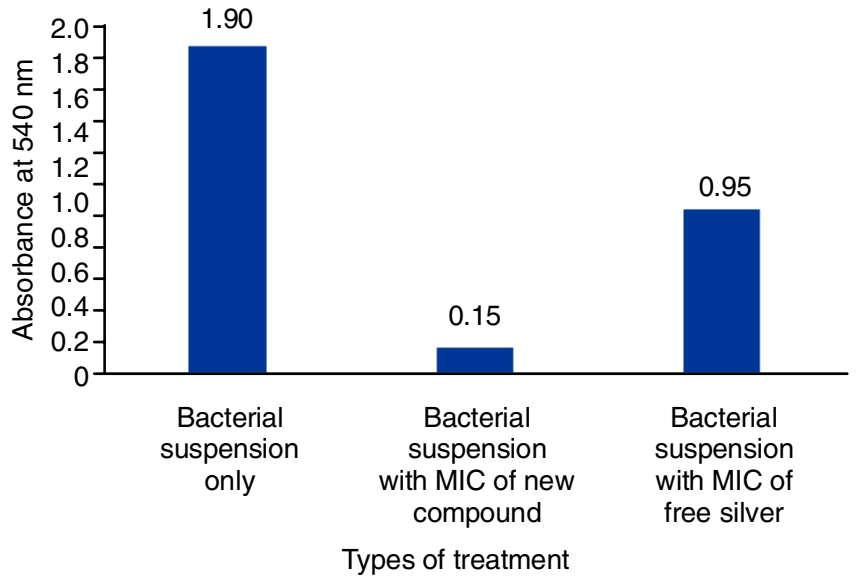

Fig. 4. Antibiofilm activity of new compound on bacterial cell

O.D.) as shown in Fig. 4. When conventional antimicrobial are not able to eliminate bacteria the alternative materials such as $\left[\mathrm{Ag}(\mathrm{APTES})_{2} \mathrm{NO}_{3}\right]$ acting as very efficient antimicrobial agents [34]. The mechanism of antibiofilm acting caucused by direct interaction of silver ions with bacterial cell membrane [35]. Therefore, the Gram negative bacteria are much more effective than Gram positive bacteria because present relatively thick cell wall [36].

\section{Conclusion}

3-Aminopropyltriethoxysilane (APTES) was reacted with silver nitrate to form $\left[\mathrm{Ag}(\mathrm{APTES})_{2} \mathrm{NO}_{3}\right]$ complex. Molar conductivity measurement showed that the complex is non-electrolyte. The TGA/DTA shows the complex could be stable and may decompose above $334^{\circ} \mathrm{C}$. The evidence from the other spectroscopic techniues showed the successful formation of silver 3-aminopropyltriethoxysilane complex.The new complex also showed largely antibacterial effect against $P$. mirablis bacteria isolated from patient with urinary tract infection.

\section{ACKNOWLEDGEMENTS}

The authors thank Kerbala University, Kerbala, Republic of Iraq for financial support.

\section{REFERENCES}

1. M.B. Gholivand, M.M. Abolghasemi and P. Fattahpour, Chromatographia, 74, 807 (2011); https://doi.org/10.1007/s10337-011-2146-8.

2. E.P. Plueddemann, Silane Coupling Agents, Springer: USA, edn 2 (1991).

3. M.T. Goldani, A. Mohammadi and R. Sandaroos, J. Chem. Sci., 126, 801 (2014); https://doi.org/10.1007/s12039-014-0619-7.

4. Ebenezer. R1, Sheela, Int. J. Emerging Trends Pharmaceut. Sci., 2, 5 (2013).

5. A. Simon, T. Cohen-Bouhacina, M.C. Porte, J.P. Aime and C. Baquey, J. Colloid Interface Sci., 251, 278 (2002); https://doi.org/10.1006/jcis.2002.8385. 
6. U.G. Singh, R.T. Williams, K.R. Hallam and G.C. Allen, J. Solid State Chem., 178, 3405 (2005); https://doi.org/10.1016/j.jssc.2005.08.023.

7. S. Jana, B. Dutta, R. Bera and S. Koner, Langmuir, 23, 2492 (2007); https://doi.org/10.1021/la062409t.

8. S. Attia, A. Shames, I. Zilbermann, G. Goobes, D. Meyerstein and E. Maimon, Dalton Trans., 43, 103 (2014); https://doi.org/10.1039/C3DT51962G.

9. S.G. Shyu, S.W. Cheng and D.L. Tzou, Chem. Commun., 2337 (1999); https://doi.org/10.1039/a907207a.

10. M. Liu, K. Hidajat, S. Kawi and D.Y. Zhao, Chem. Commun., 1145 (2000); https://doi.org/10.1039/b0026611.

11. X. Feng, G.E. Fryxell, L.-Q. Wang, A.Y. Kim, J. Liu and K.M. Kemner, Science, 276, 923 (1997); https://doi.org/10.1126/science.276.5314.923.

12. C. Muller, M.A. Schneider, T. Mallat and A. Baiker, J. Catal., 192, 448 (2000); https://doi.org/10.1006/jcat.2000.2859.

13. D.A. Agnese, T. Angelo, D. Roberto, B. Marcella, P. Maddalena, D. Giacomo, C. Lucia, P. Piersandro and G. Pietro, Nanomaterials, 7, 7 (2017); https://doi.org/10.3390/nano7010007.

14. I. Vukoje, V. Lazic, V. Vodnik, M. Mitric, B. Jokic, S. Phillip Ahrenkiel, J.M. Nedeljkovic and M. Radetic, J. Mater. Sci., 49, 4453 (2014); https://doi.org/10.1007/s10853-014-8142-2.

15. H.J. Klasen, Burns, 26, 117 (2000a); https://doi.org/10.1016/S0305-4179(99)00108-4.

16. E.J. Baron and S.M. Finegold, Diagnostic Microbiology, The C.V. Mosby Company, Baltimore, USA, edn 8 (1990).

17. J.G. Collee, A.G. Fraser, B.P. Mjarmion and A. Simmons, Mackie and McCartney Practical Medical Microbiology, Churchill. Livingston. USA, edn 14 (1996).

18. J. Vandepitte, J. Verhaegen, K. Engbaek, P. Rohner, P. Piot and C. Heuck, Basic Laboratory Procedures in Clinical Bacteriology, World Health Organization (2003)

19. T. Mathur, S. Singhal, S. Khan, D.J. Upadhyay, T. Fatma and A. Rattan, Indian J. Med. Microbiol., 24, 25 (2006); https://doi.org/10.4103/0255-0857.19890.

20. N.C. Maldonado, C. Silva de Ruiz, M. Cecilia and M.E.A. Nader-Macias, ed.: A. Mendez-Vilas, A Simple Technique To Detect Klebsiella BiofilmForming-Strains Inhibitory Potential of Lactobacillus fermentum CRL 1058 Whole Cells And Products, Communicating Current Research and Educational Topics and Tends in Applied Microbiology, pp. 52-59 (2007).

21. J.B. Patel, F.R. Cockerill, P.A. Bradford, G.M. Eliopoulus, J.A. Hindler, S.G. Jenkins, J.S. Lewis II, B. Limbago, L.A. Miller, D.P. Nicolau, M. Powell, J.M. Swenson, M.M. Traczewski, J.D. Turnidge, M.P. Weinstein and B.L. Zimmer, Methods for Dilution Antimicrobial Susceptibility Tests for Bacteria that Grow Aerobically; Approved Standard, edn 9 CLSI Document M07-A10. Wayne, PA: Clinical and Laboratory Standards Institute (2015).

22. P.R. Shukla, Advance Coordination Chemistry, Himalya Publishing House, New Delhi, India, pp.165-204 (2012).

23. C. John, Interpretation of Infrared Spectra: A Practical Approach, Encyclopedia of Analytical Chemistry, John Wiley \& Sons (2006)

24. E.R. Lippincott, A. Vanvalkenburg, C.E. Weir and E.N. Bunting, $J$. Res. Natl. Bur. Stand., 61, 61 (1958); https://doi.org/10.6028/jres.061.009.

25. G.S. Ahmed, M. Gilbert, S. Mainprize and M. Rogerson, Plast. Rubber Compos., 38, 13 (2009); https://doi.org/10.1179/174328909X387711.

26. F.A. El-Saied, M.I. Ayad and S.A. Aly, Transition Met. Chem., 18, 279 (1993); https://doi.org/10.1007/BF00207946.

27. R.C. Maurya, D.D. Mishra, S. Jain and M. Jaiswal, Synth. React. Inorg. Met.-Org. Chem., 23, 1335 (1993); https://doi.org/10.1080/15533179308016690.

28. N.K. Fayad and H.A Taghreed, Adv. Phys. Theories Appl., 9, 1 (2012).

29. N. Raman, S. Ravichandran and C. Thangaraja, J. Chem. Sci., 116, 215 (2004); https://doi.org/10.1007/BF02708270.

30. N.T. Yulia, Proton NMR studies of Functionalized Nanoparticles in Aqueous Environments, University of Iowa, Spring (2014).

31. M. Nasim, P. Tharmaraj and P.S. Venkataramani, Synth. React. Inorg. Met.-Org. Chem., 29, 1249 (1999); https://doi.org/10.1080/00945719909349526.

32. D.C. Sulikowska, A. Malinowska and J.R. Doczekalska, Pol. J. Chem., 74, 607 (2000).

33. M. Priebe, J. Widmer, N. Suhartha Löwa, S.-L. Abram, I. Mottas, A.-K. Woischnig, P.S. Brunetto, N. Khanna, C. Bourquin and K.M. Fromm, Nanomedicine, 13, 11 (2017); https://doi.org/10.1016/j.nano.2016.08.002.

34. J.R. Morones, J.L. Elechiguerra, A. Camacho, K. Holt, J.B. Kouri, J.T. Ramirez and M.J. Yacaman, Nanotechnology, 16, 2346 (2005); https://doi.org/10.1088/0957-4484/16/10/059.

35. S. Svensson, F. Suska, L. Emanuelsson, A. Palmquist, B. Norlindh, M. Trobos, H. Bäckros, L. Persson, G. Rydja, M. Ohrlander, B. Lyvén, J. Lausmaa and P. Thomsen, Nanomedicine NBM, 9, 1048 (2013); https://doi.org/10.1016/j.nano.2013.04.009.

36. S. Mohanty, S. Mishra, P. Jena, B. Jacob, B. Sarkar and A. Sonawane, Nanomedicine NBM, 8, 916 (2012); https://doi.org/10.1016/j.nano.2011.11.007. 